\title{
The Power Struggle Between the Military and the Islamists—The Future of Egypt
}

\author{
Ahmed Y. Zohny \\ Coppin State University, Baltimore, USA
}

\begin{abstract}
This work traces the historical development and impact of the Muslim Brotherhood's and the Military's informal organizations on the Egyptian Society from the last century to date. In this article, the author asserts that understanding each group perceptions of themselves and one another, their role, and the roles of other political actors in the Egyptian society, and the associated organizing concepts of agents of change, institutional reforms, civic society, and democracy is essential for accurately analyzing and understanding the changing nature of the military and the Muslim Brotherhood power struggle within the parameters of the Egyptian political-religious culture.
\end{abstract}

Keywords: informal realm, informal organizations, agent of change, civic society, democracy

\section{Introduction: The Informal Realm}

Laila Alhamad, a social development specialist with the World Bank, argued that the most ubiquitous forms of participation in the Middle East region are those of the informal realm, many of which are perpetuated by the rigidity of the formal political sphere. When the state, through its institutions, represses, excludes, or fails to listen or respond to people's needs, people resort to the informal realm. From the Jmaas in Morocco to neighborhood networks in Cairo, Egypt, the informal sphere has existed in the region throughout the ages, facilitated by a strong family ethos and a feeling of community, solidarity and kinship. While the decades following independence saw the rise of formal institutions and organizations, none has been able to challenge the strength and pervasiveness of these informal channels in Middle Eastern life. To bolster her argument Alhamad stated that many of the formal organizations of the Middle East governments have been suffused by patterns characteristic of the informal realm. Historically both the military institution and the Muslim Brotherhood (MB) social movement have their own informal organizations in the Egyptian society more than any other social or political forces in the Egyptian political system.

Understanding the formal, operational or informal organization of any system is important in understanding not only how a system appears on paper, but how it actually works, and how the parts are connected within the whole. The Egyptian political system, like others, is formally constructed and designed, although what appears to be the hierarchy may be no more than impressive-sounding titles that often do not truly reflect the real sources of power and influence within the system. On the other hand, the informal or

Ahmed Y. Zohny, Ph.D., Chairman, Department of Applied Social \& Political Science, College of Behavioral \& Social Sciences, Coppin State University.

Correspondence concerning this article should be addressed to Coppin State University 2500 West North Avenue, Baltimore, Maryland 21216. 
operational organization of the system points out who commands power makes the decisions and actually moves the wheels of the system and governs. Whether or not the formal organization is effective depends very often on the efficiency, honesty and loyalty of members of the informal organization and their support of not only each other, but the formal organization. The informal organization is composed of groups which are connected within the system and whose loyalties are formed and power basis established as a result of the bandings of these groups having similar backgrounds, education, association, and or fellowship in a mono-religious/social organization (i.e., army or police officers members of the same class-Duffa, or a small group of friends who work closely together to obtain individual goals and career advancement in the civil service, military, public sector, or the political elite- Shilla. A Shilla in the Egyptian cultural terminology may result from acquaintance in a Duffa, or a formal organization or from one's family connections. The MB has its own formal and informal organization deeply rooted in the Egyptian Society (urban and rural) since its establishment in 1928 and the Egyptian Military has its formal and informal organization deeply rooted in the Egyptian society (rural and urban) since the 1952's revolution led by the Army's Free Officers Corp (FOC).

This research will trace the historical development of the Military's and MB's informal organizations, their perceptions of themselves and other political actors, its role, its impact on the Egyptian society, and the potential of each to leading Egypt toward institutional changes to democracy and civic society. More precisely, our discussion centers on three questions: (1) What are the informal organizations of both the military and MB? (2) What is the impact of these informal organizations on the Egyptian Society? (3) Can the informal organizations of the military and MB contribute to institutional changes to democracy and civic society?

\section{Informal Organizations \& Politics}

Julia R. Azari and Jennifer K. Smith noted that scholars of the developing world have driven a surge of interest in unwritten or informal organizations as determinants of political outcomes. By contrast, in advanced democracies, informal organizations often remain consigned to the analytic margins. Azarie and Smith define informal organizations as, "Socially shared rules, usually unwritten that are created, communicated, and enforced outside of officially sanctioned channels". In other words, informal organizations exist when shared expectations outside the official rules of the game structure political behavior. Delbert C. Miller and William H. Form define informal organizations as being,

composed of the animosities and friendship among the people who work together. It contains the primary groups, cliques and congenially groups that develop in shop or office. It further consists of the folkways, mores, norms, and values which guide the behavior of workers sometimes in fulfillment of the goals of a formal organization, and sometimes in the blockage of those goals. In fact, the relation of the informal organization to formal organization determines how effective the latter functions.

Azari and Smith (2012) argued that the informal organizations can perform the following functions: (1) develop informal rules that can fill gaps and resolve ambiguities in formal organizations; (2) be parallel, in the sense that informal and formal rules can jointly regulate the same behavior; and (3) play a coordinating function, in the sense that informal rules can integrate the operation/output of multiple intersecting institutions.

\section{The Informal Organizations of MB and the Military}

\section{The MB Informal Organization (MBIO)}

Nathan J. Brown (2012) argued that Egypt's Muslim Brotherhood (MB) has set the pattern for other 
Islamist movements and many of the various movements it spawned in other countries continue to refer to the original Egyptian organization as the "mother movement". The MB's unique organizational features of being flexible, with a focused vision and engaging, its general emphasis on reform and the effective operation of its informal organization (MBIO), have set the example and tone that other movements have tried to follow. The MBIO’s norms, regularities, and informally institutionalized behavior as described by Azari and Smith, evolved, according to Saad Eddin Ibrahim, from the necessity of survival in the complicated realities of Egyptian politics in the last 84 years - under the monarchy for 24 years and under military dictatorships for 59 years. For all the MB's problems attaining legal status in the last 84 years, the MBIO still strives to have bylaws, clear criteria for various graduations of membership, regular internal arrangements, established procedures for selecting officers, determining policies and positions, collegial and consultative decision making organs, and specialized bodies with clear functions tasks. Since its establishment by Hassan al-Banna in 1928, the MB movement, according to historians was used and abused by its members - and also by Islamists who constitute a broad category that includes diverse individuals converging on the goal of creating a sociopolitical, legal and economic order based on interpretations of Islam, not only as a religion, but also as a social and legal system. The MB was also used and abused by powerful political actors in Egypt such as Kings Fouad and Farouk, corrupt political parties and politicians, and other movements such as the Free Officers movement inside the Egyptian Army.

The MB's entry into political activity in Egypt began early but appeared cautious and almost diffident at first. In the 1930s, the organization eschewed tight political alliances but still found itself in rivalries among Egyptian Political forces (sometimes earning itself a reputation for being close to the palace or to particular politicians). In addition to forming political alignments, MB's leader Hassan al Banna focused on a few specifically Islamist causes that had salient political overtone such as: Christian missionary activities, British imperialism, and the brewing conflict between Arabs and Jews in Palestine. From 1923 to 1952, the MB was perceived by the capitalists liberal ruling elite (during the monarchy time), as part of the Egyptian political landscape. It played an important role in the struggle against the British and the Zionist. During the 1940s (particularly during and after WWII's complicated events), the MB got caught several times in the power struggle between King Farouk, the British ambassador (the De Facto ruler of Egypt), and other political parties. The MB was outlawed and its activities were suspended when their underground militia was accused of assassinating two prime ministers of Egypt, Ahmed Maher (1945) and Mahmud Fahmy al Nokrashy (1946). After the1952 revolution and two years of honeymoon between the MB and the free officer's corp (who ousted King Farouk), leaders of the MB got caught in the power struggle between Nasser, supported by the majority of the free officers, and General Mohamed Naguib, the mostly forgotten leader of the July 1952 revolution that ousted the Egyptian monarchy. Naguib had favored the restoration of Egypt's parliamentary democracy; Nasser favored a continuing populist revolution under the supervision of the military. The MB was in the middle of the aforementioned power struggle and was accused of planning and implementing the unsuccessful assassination attempts on Nasser's life in 1954. Consequently, the MB was outlawed and its members tried, executed or jailed for a long time without fair trial, despite the fact that the MB was among many secret movements within Egypt (including the army free officers corp), which were poised to overthrow King Farouk. In portraying the relationship between the Egyptian military and the MB, Goldschmidt argued that the 1952 revolution had been a classic army coup, not a popular uprising. If the free officers wanted to gain and hold the people's support, they had to appeal to groups and/or social movements that have wide popular support at the grass roots level, 
even if these groups or social movement have different views of the free officers corps. The MB satisfied these attributes and the free officers cooperated with them to strengthen the Revolutionary Command Council's RCC's power over the government. Nasser tolerated MB, but once the RCC was clearly in control, it could no longer share power with its rivals, among them the MB, old regime politicians, communists, trade unions, Al-Wafd party and other political parties and social movements operating in Egyptian politics. According to Saad Elddin Ibrahim, even though the MB had been outlawed, its parallel informal underground organization (MBIO) continued to operate through person to person contacts in every Egyptian village and city, using forums that could support their activities and incubate it far from Nasser's security apparatus. The MB's ability to survive as a movement was due to the fact that it was founded on the ideological antecedents of Jamal Al deen Al Afgani; Muhamed Abdu and Rashid Rida of the second part of the 1800 century. This historical continuity, according to Ibrahim, should dispel current western views-which see Islamic movements everywhere as if they sprung out of nowhere.

President Sadat of Egypt (1971-1981) used the MB to advance his political goals. The growth of political Islam in the last 40 years with its defining features of Egyptian society goes back to the early 1970's when Sadat allowed Islamic groups, including the MB to operate informally in Egyptian society. Tarek Osman argued that President Sadat unleashed Egypt's Islamic forces including the MB when he released thousands of the MB's leaders and members from jail, and allowed the MB's old newspaper the Call (Al-Dawaa) to be reissued. He encouraged them further by trying to assume the mantle of Islam, calling himself "the guardian of the faith". Also, he emphasized that his first name was "Mohamed", not "Anwar". Furthermore, Sadat promoted religious schools by authorizing a major increase in the budget of Al-Azhar University and the expansion of its parallel education system. And he opened the door for leading religious scholars and commentators to dominate the state-controlled media, introduced apostasy laws in Egypt after years of a highly liberal intellectual atmosphere, declared sharia law (Islamic jurisprudence) as the principle source for the Egyptian constitution and declared himself the leader of "an Islamic pious country". In less than a decade, the Egyptian state became quasi-Islamic, replacing the civic nature of the 1950s and 1960s. To consolidate his power, Sadat felt that Islamic groups including the MB would counterbalance the combined opposition to his regime mounted by Nasserite and leftist elements, according to Saad Eddin Ibrahim.

Despite the fact that the MB was allowed to operate tacitly during the Sadat regime, other Islamic movements such as the Sufi, the retreats movement, the Salafist, Repentance and Holy Fight (RHF), and the Islamic liberation Organization (ISO)—none of them were able to acquire a legal status or license through the Ministry of Social Affairs. The MB's informal organization (MBIO) was able to operate more freely in the informal realm, than any other Islamist organization in Egypt during Sadat's Regime. The MB emphasized two operational principles-one strategic and one tactical. The strategic principle is an assertion of its longstanding call for the establishment of an Islamic social order on the basis of the Shari'a. The tactical principle is the assertion that the $\mathrm{MB}$ is seeking its strategic objective in Egypt nonviolently through conscious raising of the Muslim masses and advice to "Muslim” rulers. The MB's leadership has detached itself from other Islamist groups which engage in violent confrontation against the Sadat regime. But the MB, however, through the MBIO, was able to cautiously form an opposition to the four major policies initiated and implemented by Sadat, which gradually proved to be harmful to the Egyptian people: the open door economic policy, democratization, alliance with the west and conciliation with Israel. The aforementioned policies evolved with repression measures concurrently. The last years of Sadat's presidency were the crucible of a peace and a police apparatus, 
reminiscent of Nasser's rule.

Shadi Hamid observed that, for the members of Egypt's MB - the oldest and most influential Islamist force-the Arab Spring and the January 25, 2011 revolution against Mubarak may not have been of their making, but it surely was the answer to their prayers. As recently as December 2010, the group's members were routinely rounded up by security forces (including the current elected president Mohamed Mursi). Mubarak's regime had manipulated the November 2010 election even worse than usual, leaving the MB with zero seats in parliament (compared to their previous share of 88 seats, or $20 \%$ of seats in the 2005 parliamentary election). During the 30 years of Mubarak's autocratic regime, the MBIO continued to operate in the informal realm, and participate in the Egyptian policy process, despite the fact that the Egyptian security apparatus regained and even exceeded the powerful role it played under Nasser (1952-1970). With the overwhelming grip of the state through its coercive apparatus on political life, and the increasing economic needs that have gone unmet, people have resorted to the traditional informal modes of participation to access resources, curry favors, and have a voice in everyday political, economic and social matters. As NazihAyubi notes, since the Egyptian state has managed to encircle the society to this extent, the MBIO enabled the people (particularly in the poor rural and urban areas) to get engaged through forums near to where they live. This includes the mosques, Zawaya, religious orders and brotherly solidarity that have been re-embraced by the popular forces, at a time when nationalist and leftist elites are still struggling to turn their civil associations and societies into viable structures for rejuvenating the civil society.

\section{The Military Informal Organization (MIO)}

The first phase of the establishment of the MIO started in 1954 when Nasser first positioned in power the Revolutionary Command Council of the Free Officers Corp (RCC-FOC)'s members and around 300 army officers who comprised the free officers Corp. in the major ministries, over civilians. Nasser became deputy Prime Minister and Interior Minister. At this stage, the free officers controlled the decision making process in domestic and foreign affairs and started the practice of appointing military and police officers in senior decision making positions in the Egyptian central government, and the 27 Egyptian Governorates (states). Nasser used his new position as a Minister of Interior to reduce the influence of the communists and the Marxist left, and to liquidate the $\mathrm{MB}$, the only social and political force competing with the military in the Egyptian political process, after accusing them of conspiring to assassinate him. Nasser dashed all hopes of a return to civilian rule in 1954 by conspiring and displacing General Mohamed Naguib, the mostly forgotten leader of the July 1952 Free Officers revolt against the Monarchy according to Robert Springborg. Anour Abdel Malek documented this development in his excellent and well documented book: Egypt: Military Society, The Army Regime, The Left, And Social Change under Nasser, published in 1978. Since this time, Nasser institutionalized Personal Rule rather than Rules in the Egyptian policy process. To borrow Robert Jackson and Carl Rosbeg's definition, the Egyptian system of government became a system where "persons take precedence over rules, where the officeholder is not effectively bound by his office and is able to change its authority and powers to suit his personal and political needs". In such a system of personal rule, the rulers and other leaders take precedence over the formal rules of the political game. The rules do not effectively regulate political behavior, and people therefore, cannot predict or anticipate conduct from knowledge of the rules. To put this in comparative government terms, the state is a government of men and not of laws. As a result, from 1954 to February 11, 2011, Nasser's, Sadat's and Mubarak's presidencies have rendered Egypt to be one of the most 
resilient personal authoritarian systems in the World.

The second phase of establishing the MIO took place on July 23, 1961, with Nasser's introduction of the socialist ideology and the adoption of centralized national planning as a strategy for social and economic development. This resulted in the complete nationalization of all foreign and private assets and corporations in Egypt, establishing the Public Sector as an agent of change in the government. And the passage of the new local government law and adopting planned development. As a result, a reorganization of the Egyptian public administration was needed to fit Nasser's personalized rule. Army and loyal police officers were transferred from their military and police positions to lead new organizations within the public sector corporations and regional organizations related to development. Gradually, an informal organization was established in the Egyptian public bureaucracy. The power bases of this informal organization were the Ministry of War (the Armed Forces), the Ministry of Interior (the Police Forces), and the Intelligence Service (whose members are selected carefully from both the armed and police forces). The MIO’s power and influence was institutionalized through the army's and police's Duffa linkages. Duffa is the Egyptian equivalent of the "Old Boy Network" in the western culture. Duffas from the two military academies, the Army Academy and the Police Academy, generated strong loyalties and mutual obligations compared to their western counterparts. During Nasser's time, and with his tacit blessing, members of the MIO who had a police background did not socialize with those who had army background, and vice versa. The loyalty of both categories of officers to their respective power bases contributed to maximizing segmentation rather than integration in the MIO. Nasser used this to create a system of a balanced tension between the two groups. And each group reported to him any acts of disloyalty by the other group. Both groups have to perform the same functions of managing development programs, supervising and controlling the Egyptian bureaucracy and maintaining national security, which is meshed or intertwined Nasser's personal security. Loyalty to Duffa in the MIO was unintentionally a force for coordinating the activities of the formal organizations of the Egyptian bureaucracy, the main agent of change after nationalizing the economy and adopting planned development, through initiating informal rules integrating the operation/output of the multiple, intersecting organizations within the Egyptian bureaucracy.

An important difference among Nasser's, Sadat's and Mubarak's regimes is that the balanced tension encouraged by Nasser among the three branches of the MIO gradually started to fade away during Sadat's and Mubarak's regimes. The formal organizations of the state coercion apparatus (the Ministry of Defense, The Ministry of the Interior, and the Intelligence Service) started to work very well together since the beginning of Sadat's administration due to the circumstances of preparing the state for war against Israel, and the important role the police's leadership (led by police General Mamdauh Salem) to support Sadat in 1971 when the old guards of Nasser's regime tried to overthrow him. The three bases of power developed a very good working relationship with each other and learned how to coexist with one another. Also, the unwritten roles, of giving admission preferences to the Police and Army Academies to the sons and daughters of police officers, and army officers over other social classes, made the three institutions of the Army, the Police and the Intelligence Service very protective of one another. By the end of Mubarak's regime, the three organizations almost constituted one large elite organization (or one big family) subordinated and loyal to the President and his dominant political party - the National Democratic Party (NDP). The above circumstances have its impact on the MIO, which gradually penetrated and controlled the economy. Steven A. Cook documented the MIO penetration and heavy involvement of the Economy as of Sadat's administration. He noted that "once Anwar Sadat came to power in 1971, a nexus between private economic interests and the military developed". The 
new president's policy of infitah (opening the economy) allowed members of the military enclave and the economic elite to benefit mutually from the "commission game" which enriched the officers and ensured that, in return, contracts from the military continued to flow.

\section{The Impact of MBIO \& MIO on Egyptian Society}

\section{The MBIO}

The literature related to informal organizations and or operational organizations in the Middle East is still in its infancy. The bulk of the contemporary literature tends to concentrate on extremist networks. Drawing examples from the Mosques and Islamist networks of Cairo, Mounia Bennani-Chribi and Oliver Filliele (2003) give a taste of the various modes of participation in Egypt that are based on operational rather than theoretical definitions of political participation, the later being based on Western political theory. Similarly, demonstrating that political participation extends beyond participating in formal organizations, Diane Singerman skillfully documents the various ways of informal participation taken by the Egyptian people to create public space and penetrate what is conventionally considered the public arena as they connect individuals, households, and communities to the state bureaucracies, public institutions and formal political institutions to fulfill individual and collective needs. Asef Bayat reveals a world of clever forms of political participation and mobilization among the popular Egyptian classes. Without using the aforementioned subtle forms of informal participation organized by the MBIO, the electoral victory of former President Mohamed Mursi-the candidate of the Freedom \& Justice Party (FJP), the first formal political organization of the MB movement, would not be possible.

Marina Ottaway of Carnegie Endowment for International Peace described Mursi's victory as the first piece of good news for Egypt's transition under military custodianship. She noted that after SCAF dissolved the parliament and assumed legislative functions, amending the constitutional declaration it had issued in March 2011 in order to increase its own power and protect the military from civilian oversight, and de facto asserting its control over the writing of the new constitution, it did not dare to go the last step and also declare General Ahmed Shafiq, its preferred candidate and a representative of the old regime, the winner.

Maye Kassem noted that political Islam in its contemporary, participatory, and popular form emerged in 1928 with the establishment of the society of Muslim Brotherhood under the umbrella of a charitable society. The original aim of its founder, Hassan al Banna, was "To reform [the] hearts and mind, to guide Muslims back to the true religion and away from the corrupt aspirations and conduct created by European dominance". Active political participation by MB emerged on several levels and in conjunction with a broad range of social and educational activities delivered to the Egyptian people at the grassroots level. Al-Banna attempts to encourage social reforms included a strategy to teach children in the daytime and their parents at night. In the early 20th century, when education in the Egyptian society was limited to a small section of the population, the MB's charitable Islamic education undoubtedly contributed to its expansion across the country. This expansion and popularity of the MB's as organization was due to the hard work, dedication and focused vision of its leadership, as pointed out by Richard Mitchell. Al-Banna and selected deputies pursued the MB's goals by direct communication with the people in the mosques, at their homes, work and places of leisure. They toured the countryside on the weekends and during vacations. This is created legitimacy, sincerity and the personal touch.

The popularity of the MB was further enhanced under the monarchy from the 1930s until 1952 (King 
Fouad and his son King Farouk), was due to their consistent defense of the national cause (Palestine, and Egypt's independence from the British). And during the first republic of three military dictators (Nasser, Sadat, and Mubarak), from 1954 to 2011, it was the MBIO's ability to provide social services to the growing number of the poor population in both the rural and urban areas in the form of basic education, health care, food supplies, and humanitarian relief during natural disasters, in times when the largely corrupt bureaucracy of the state could not provide these badly needed services. The MBIO, through its informal networks was also, the vehicle of political participation of lower and upper middle class. Tapping into the layers of social ties and mutual trust that thrive in Egypt (and other countries in the Middle East), the MBIO networks fulfilled a multitude of purposes and as such created positive and less risky incentives for political participation in Egypt. Alhamad argued that these incentives, both material and nonmaterial, include furthering personal interests usually related to tapping into state resources, providing a conduit of information, building key alliances, and challenging the state's monopoly on reigning ideologies.

\section{The MIO}

Nasser's, Sadat's and Mubarak's dominance and style of role of 60 years, as well as the MIO's mode of operation have led to gaps, tensions and imbalances in the Egyptian society. The two groups with military and police background regarded themselves as superior to the majority of the civilian bureaucrats in a system which relied heavily on the state for employment. Hence, ethnocentrism and social distance gradually developed between members of the MIO and the rest of the Egyptian society. It resulted in the following:

1. Discriminatory practices against the civilians and in favor of the military in terms of salaries, promotions and recruitment to high managerial and political positions during Nasser's regime, have led to a systematic brain drain of Egypt's valuable human resources. The process of immigration of the educated talented population (Copts Christians and Muslims) started as early as the 1960's to Europe, USA, Canada, and Australia. And Egypt lost at least 10 million of its best human resources.

2. Nasser's and Sadat's dominance and style of role of almost 30 years, and the 30 years length of Mubarak's regime ruling by Emergency Law, have well consolidated and cemented the MIO infrastructure. The MIO flourished and expanded its operations under the full protection of the police power of the regime and its hegemony over all aspects of political, economic and social affairs of Egyptian life. It created what Eva Bellen called "Robustness of the Coercive Apparatus" in Egypt.

3. As a result of a 60 years of military dominance, Egypt became a "Soft State" according to the economist Galal Amin of the American University in Cairo, Egypt. A soft state is a state that passes laws but does not enforce them. The military elites in Egypt can afford to ignore the law because their power protects them from it, while others pay bribes to work around it. The rules are made to be broken and to enrich those who break them, and taxes are often evaded. As a result, corruption is generalized and the payment of bribes is widespread; the weakness of the state encourages corruption, and the spread of corruption have further weakened the Egyptian state. In 2010 toward the end of Mubarak's Regime, Egypt was ranked by Transparency International's Corruption Perception Index (CPI) as number 112 out of 180. Shana Marshall and Joshua Stacher noted that "before and after the ejection of Hosni Mubarak from office the size of the Egyptian army's share in the economy has been a subject of great debate". But evidence indicates that the military, police and intelligence services share in the Egyptian economy is 50\%, $40 \%$ for the army, $5 \%$ for the police, and $5 \%$ for the intelligence service according to historians Muhamed Al-Gawady, Asem Al-Dissoky, and Kalid Fahmy. 
The broad range of figures drives home the impossibility of measuring the footprint of what scholar Robert Springborge calls "Military, Inc.”. The army, intelligence service and police holdings (operated by the MIO) are classified as state secrets—reporting on them can land a journalist in jail—but they are also too vast and dispersed to estimate with any confidence. Egyptian journalist Abdul Halem Kandel confirmed the aforementioned large share of the Egyptian economy by the army exceeds 1/3 of the Egyptian Economy. All the economic activities of the army, police and the intelligence service are not taxable according to a senior official in the Egyptian Revenue Agency who refused to be identified. Also, the National Auditing Agency is not allowed to audit their financial statements. Heba Handoussa and Noha El-Mikawy observed also, the following weaknesses characterized the Egyptian economic regime under the military dominance in their valuable study of Institutional Reform \& Economic Development in Egypt, published in 2002: Weak link between policies of liberalization and institutional reforms; laws enacted by the legislation are arbitrary enacted (with weak social input) and vaguely written, and the process of enacting them is not transparent, with heavy executive involvement in legislation; the role of interest groups and professional organizations in policy making and law making is still marginal; and Egypt's export performance is still very weak by developing country standards.

4. Since the revolution, there has been open criticism of a once-untouchable military institution-its long standing shadow economy, its post-revolt trials of thousands of civilians and "virginity tests" of detained women, and its blatant power grabs of issuing a constitutional amendment on the eve of President Mursi's election giving themselves vast powers of weakening the presidency. This has shaken the military's reputation like never before. Likewise, the hidden but effective presence of the MIO is seen and felt during the transition period where SCAF poorly ruled the country.

\section{Can the MB and the Military Be Agents of Change to Democracy?}

\section{The MB}

A closer examination of the year during which Morsi was theoretically in power shows a different picture of an administration with little power to impose its policies, according to Marina Attaway.

Woodrow Wilson International Center For Scholars Morsi would undoubtedly have liked to appoint Islamists to important positions in all government institutions, and he did so when he could, but he was hemmed in from the very beginning by the military, the courts, the ministry of interior, the security apparatus, and the top levels of the bureaucracy, and the MIO or the deep state. The Morsi administration was undoubtedly politically incompetent and ineffective. Some of his appointments showed complete lack of political judgment. For example, he chose Adel Asaad Al-Khayat, a member of an organization that had perpetrated a massacre of tourists in Upper Egypt in November 1997, to be governor of Luxor. And certainly Morsi failed to make even minor efforts to meet the challenges of Egypt's economic problems-but the same was true of the SCAF before him and the military-appointed government after he was deposed. After he was inaugurated as president on June 30, 2012, Morsi made an attempt to challenge the SCAF, calling its decision to dissolve the parliament traversing and overlapping previously announced ones, without anything happening in practice. In late November, 2013, opposition parties finally managed to come together in a single National Salvation Front, but the real protagonists of the political drama remained Morsi and the Brotherhood, the SCAF, and the courts.

To understand Egypt's current political situation, it is crucial to examine how and why the Muslim 
Brotherhood—a leading political actor just over a year ago-met its demise so suddenly and forcefully. According to Asheraf El-Sherif of Carnegie Endowment for International Peace, fell because of its own political, ideological, and organizational failures (both formal \& informal organizations). Firstly, the organization's inclusion in the political system did not lead to its democratization and moderation, as some observers had predicted it would. Instead, the lack of political consensus in Egyptian society combined with the Brotherhood's unwillingness to undergo a process of ideological and organizational transformation undermined the group's democratic potential. Secondly, the Brotherhood's leadership was made untenable by its inability to placate the powerful old state or win over crucial elites and other political actors. Thirdly, ideological hollowness and opportunism undercut the Brotherhood's claims to a legitimate "Islamic democratic project", and the organization's structural deficits led it to be widely distrusted. Fourthly, the Brotherhood's failure to transform electoral victories into sustainable political control effectively eliminated the possibility of Islamist domination. While its fall did not signify the end of political Islam in Egypt, it did mark the end of the utopian idea held by some that "Islam is the solution".

\section{The Military}

Joseph de Rivera, in his analysis of perceptions and reality, asks questions concerning the determinants of choice. His proposition concerning the subject is that "the choice that is actualized is the choice which does not contradict one's other beliefs". And the "perception that actually occurs is the one that requires the least reorganization of the person's other ideas”. It follows then that unless the person's beliefs and perceptions are in line with an objective reality then the decisions made on the basis of those beliefs and perceptions are subject to error. Such propositions are equally applicable to persons as well as to organizations, institutions, social movements and nations, who are in fact led by persons governed by individual beliefs and perceptions. Evaluating the performance of Nasser, Sadat, Mubarak, SCAF (representing the military institution) during the 16 months of ruling Egypt since the ejection of former President Mubarak from power in February 11, 2011 to date after electing President Abdul Fatah al-Sisy in May 26/2014, may indicate that the Egyptian military still perceive their role as a modernizing one. As outlined by the modernization paradigm dominated the social science between the 1950s and 1970s. Steven Cook noted that during that era, scholars of the Middle East such as Manfred Halpern, Lucien Pye, Eduards Shils hypothesized that relatively autonomous militaries were progressive forces of modernization and democratization. These analysts saw the military with organizational capacity, sense of mission, and nationalist sentiment as the ideal instrument to direct the process of industrialization, institutionalization and democratic reform necessary for the development of a modern civic society. Once national goals were met, the analysts assumed, the new rulers would relinquish their prestigious power positions. The empirical evidence indicated that military officers in most developing countries, including Egypt, were, indeed, successful in generating significant economic performance and carried out successful programs of economic and social development. The Egyptian government dominated and controlled by the military was able to realize the targets of the first five year plan (1960-1965) in the agricultural, industrial and social services sectors which include education, health and welfare. Also, the GNP increased from 2547.9 million Egyptian pounds to 3,738.00 million pounds. This positive trend in the performance of the Egyptian economy (where the MIO was the real operating force) was confirmed by John Waterbury. He noted that "This formula worked satisfactorily in some respects, since Egypt achieved a respectable annual GNP growth rate of about $6 \%$, although the population was growing during the same years at $2.58 \%$ per annum. 
In time, however, and after Egypt's defeat in June, 5, 1967 war with Israel and the added costs of military buildup, the state-directed economy stagnated, and the officers became conservative elements clinging tenaciously to regimes in which they were (and remain) the primary beneficiaries. These military officers, Cook noted, mostly of senior rank, make up the military enclave. They represent an elite preserve that in many ways separated from society in military—only facilities such as schools, clubs, and residential areas. In describing the Egyptian military, Hillel Frisch argued that the Egyptian army seems to possess the characteristics of a modern army (in the 1950s sense, when nationalism and patriotism unquestionably prevailed in military establishment) in a post-modern age. While the post-modern army is often seen as being professionally small, the Egyptian army remains rather large. While the post-modern army is typified by increasing civilian-military integration, the Egyptian army has constructed at least 17 military cities to isolate the military from the civilian population. Cook pointed out a more profound —and politically more salient issue, than the actual physical separation between the military and most civilians-is the distinctive perception and world view of military officers toward their civilian counterparts. Egyptian military enclaves (led by the free officers), he argued, placed the military's organizational and technological capacities in a superior position to civilians. They perceived themselves in the position of the "high modernist" par excellence. The Egyptian military's high modernisms' worldview (like their counterparts in Algeria and Turkey), placed a premium on the scientific knowledge necessary for modernization and is inherently authoritarian. According to high modernists, only those with these types of specialized skills—i.e. themselves — have a mandate to exercise political power. The successors of the free officers during Sadat's and Mubarak's regime have maintained this worldview, considering themselves to be great modernizing forces-vanguard of the Egyptian society imbued with organizational capacity superior to that of the civilian organizations. They viewed Egyptian civilian politicians as incompetent.

\section{President al-Sisi's Potential as a Democratic Reformer}

Kenneth M. Pollack of the Brookings Institute gives another reason for the inability of the military and its current candidate al-Sisi in the office of the President to be an agent of change to democracy and civil society. He noted that the Egyptian military dislike instability, for that reason, they are often uncomfortable with rapid, far-reaching political transformation associated with building strong independent civilian institutions, and especially if those transitions unfold chaotically and the end-state is unclear. It may also be that the well-ordered military mind detests the "untidiness" of difficult political transformation where independent civilian institutions will compete with them in the Egyptian policy process, and maybe very soon hold them accountable of all wrong doing in the last 60 years, where they ruled Egypt but did not govern it, according to analyst Steve Cook. Tarek Masoud noted that military institution behavior and its actions during the transition period, and to date indicate that the military do not want a genuine democracy in which the military is subject to civilian oversight. The military institution wants to retreat to some more palatable, more democratic-looking version of the status quo ante. Military personnel in Egypt typically see genuine democracy as threatening to their corporate interests, and their shadow economic activities operated by the MIO.

\section{References}

A Saban Center at The Brookings Institution Book. (2011). The Arab Awakening, America and the Transformation of the Middle East. Washington DC: Brookings Institution Press.

Abdel-Malek, A. (1968). Egypt: Military society. New York: Random House. 
AL-Gazera Interview with Abdul HalemKandel, June 17, 2012.

Amin, G. (2011). Egypt in the era of Hosni Mubarak, 1981-2011. Cairo: The American University in Cairo Press.

Azari, J. R., \& Smith, J. K. (2012). Unwritten rules: Informal institutions in established democracies. American Political Science Association: Perspectives on Politics, 10(1), 37.

Brown, N. J. (2012). When victory is not an option, Islamist movements in Arab politics. Ithaca: Cornel University Press.

Brownlee, J. (2011). Peace before freedom: Diplomacy and repression in Sadat's Egypt. Political Science Quarterly, the Journal of Public and International Affairs, 126(4), 642.

Cook, S. A. (2007). Ruling but not governing, the military and political development in Egypt, Algeria, and Turkey. Baltimore: The Johns Hopkins University Press.

El Sherif, A. (2014). The Egyptian brotherhood's failures. The Carnegi Papers, Carnegi Endowment for International Peace, Washington, DC.

El-Mahdi, R., \& Marfleet, P. (2009). (Ed.). Egypt, the moment of change. London: Zedbook.

El-Mikawy, N., \& Handoussa, H. (Eds.). (2002). Institutional reform \& economic development in Egypt. Cairo: The American University in Cairo Press.

Frisch, H. (2001). Guns and butter in the Egyptian army. Middle East Review of International Affairs, 5(2), 1.

Goldschmidt, Jr. A. (2008). A brief history of Egypt. Cairo: Checkmark Books.

H. de Rivera, J. (1968). The psychological dimension of foreign Policy. Columbus: Charles E. Merrill.

Ibrahim, S. E. (1996). Egypt, Islam and democracy, twelve critical essays. Cairo: The American University in Cairo Press.

Interview on December 29/2011 with three former Police officers, who refused to be identified by name.

Kassem, M. (2004). Egyptian politics, the dynamics of authoritarian rule. Boulder/London: Lynne Rienner Publishers.

Lust-Okar, E., \& Zerhouni, S. (Eds.). (2008). Political participation in the Middle East. Boulder: Lynne Rienner Publishers.

Marshall, S., \& Joshua. (2012). Egypt’s generals and transnational capital. Middle East Report, 42(1), 12.

Osman, T. (2012). Egypt on the brink, from Nasser to Mubarak. New Haven: Yale University Press.

Ottaway, M. (2014). Democratic transitions and the problem of power. Occasional Papers. Woodrow Wilson International Center for International Scholars, Washington, DC.

Posusney, M. P., \& Angrist, M. P. (Eds.). (2005). Authoritarianism in the Middle East, regimes and resistance. Boulder/London: Lynne Rienner Publishers.

Sherif, A. E. (2011). Islamism after the Arab Spring. Current History, a Journal of Contemporary World Affairs, 110(740), 359.

Shukrallah, H. (2011). Egypt, the Arabs, and the world. Cairo: The American University in Cairo Press.

Springborg, R., \& Henry, C. M. (2011). Army guys. The American Interest, 6(5), 16.

Telephone Interview April 16, 2012 with two ranking civilian employees of the Ministry of Local Government, who refused to be identified by name.

TV Interview, Cairo Time, June 17, 2012.

Unwritten Rules: Informal Institutions in Established Democracies, 41.

Zohny, A. Y. (1988). The politics, economics and dynamics of development administration in contemporary Egypt. Heidelberg: Books on African Studies. 